\title{
Systematic review and meta-analysis of the epidemiology of vancomycin-resistance Staphylococcus aureus isolates
}

Qianxing Wu' ${ }^{1}$, Niloofar Sabokroo², Yujie Wang ${ }^{3^{*}}$, Marzieh Hashemian, Somayeh Karamollahi ${ }^{4}$ and

Ebrahim Kouhsari, ${ }^{56^{*}}$ (1)

\begin{abstract}
Background: Vancomycin-resistant Staphylococcus aureus (VRSA) is a serious public health challenging concern worldwide.

Objectives: Therefore, the objective of present study of 62 published studies was to evaluate the prevalence of VRSA based on different years, areas, isolate source, antimicrobial susceptibility testing, and the genetic determinants.

Methods: We searched the relevant articles that focused on the prevalence rates of VRSA in PubMed, Scopus, Embase, and Web of Science from 2000 to 2019. Statistical analyses were conducted using STATA software (version 14.0).

Results: The prevalence of VRSA was 2\% before 2006, 5\% in 2006-2014, and 7\% in 2015-2020 that showed a 3.5-fold increase in the frequency of VRSA between before 2006 and 2020 years. The prevalence of VRSA was 5\% in Asia, 1\% in Europe, 4\% in America, 3\% in South America, and 16\% in Africa. The frequencies of VRSA isolated from clinical, nonclinical, and mixed samples were $6 \%, 7 \%$, and $14 \%$, respectively. The prevalence of VRSA was $12 \%$ using disk diffusion agar method, $7 \%$ using MIC-base methods, and $4 \%$ using mixed-methods. The prevalence of vanA, vanB, and vanC1 positive were $71 \%, 26 \%$, and $4 \%$ among VRSA strains. The most prevalent genotype was staphylococcal cassette chromosomemec (SCCmec) II, which accounted for $57 \%$ of VRSA. The most prevalent staphylococcal protein A (spa) types were t002, t030, and t037.
\end{abstract}

Conclusion: The prevalence of VRSA has been increasing in recent years particularly in Africa/Asia than Europe/ America. The most prevalent of genetic determinants associated with VRSA were vanA and SCCmec II. This study clarifies that the rigorous monitoring of definite antibiotic policy, regular surveillance/control of nosocomial-associated infections and intensive surveillance of vancomycin-resistance are required for preventing emergence and further spreading of VRSA.

Keywords: Antimicrobial resistance, Vancomycin-resistant Staphylococcus aureus, Systematic review and metaanalysis

*Correspondence: 18351803031@163.com; dr.kouhsari@goums.ac.ir ${ }^{3}$ School of International Pharmaceutical Business, China Pharmaceutical University, Jiangsu Province, Nanjing 211198, People's Republic of China ${ }^{5}$ Laboratory Sciences Research Center, Golestan University of Medical Sciences, Gorgan, Iran

Full list of author information is available at the end of the article

\section{Introduction}

Staphylococcus aureus is a major human nosocomial and community-acquired pathogen that causes infections of the skin and soft tissues, and life-threatening systemic diseases and is associated with the high rate of morbidity and mortality worldwide [1-3]. It remains a challenging, original author(s) and the source, provide a link to the Creative Commons licence, and indicate if changes were made. The images or other third party material in this article are included in the article's Creative Commons licence, unless indicated otherwise in a credit line to the material. If material is not included in the article's Creative Commons licence and your intended use is not permitted by statutory regulation or exceeds the permitted use, you will need to obtain permission directly from the copyright holder. To view a copy of this licence, visit http://creativecommons.org/licenses/by/4.0/. The Creative Commons Public Domain Dedication waiver (http://creativeco mmons.org/publicdomain/zero/1.0/) applies to the data made available in this article, unless otherwise stated in a credit line to the data. 
global public health crisis due to the emergence and spread of methicillin-resistant $S$. aureus (MRSA) and vancomycin-resistant $S$. aureus (VRSA) [1, 4]. Currently, MRSA and VRSA are categorized as agents of high significance with potential to cause considerably devastating worldwide mortality in the absence of effective containment and treatment options $[1,5,6]$. In addition, VRSA tends to be multi-drug resistant (MDR) against a diversity of currently available antimicrobial agents.

The glycopeptide vancomycin has been regarded as the last therapeutic agent for the treatment of infections due to severe MRSA and other resistant Gram-positive strains [7]. In 2002, the first case of VRSA was recovered in a 40-year-old Michigan woman with diabetes [8]. Hitherto, the previous in vitro literature proposed two mechanism underlying vancomycin resistance of VRSA: (1) Decreased permeability and thickened and poorly crosslinked cell wall, whereby many vancomycin molecules are trapped within the cell wall [1,9], (2) Another type of vancomycin resistance in bacteria is mediated by several van gene clusters (plasmid-mediated) that are found in some Gram-positive pathogens specially, enterococcal species [1]. A recent published systematic review and meta-analysis, by Shariati et al. [10], analyzed the prevalence VRSA, vancomycin intermediate $S$. aureus (VISA) and heterogeneous VISA (hVISA) variability depending on different years and locations.

In current comprehensive systematic review and meta-analysis, we pooled the published studies that have reported the prevalence of VRSA, and made sub-group variability of the prevalence of VRSA in different years, areas, isolate source, and antimicrobial susceptibility testing. We also analyzed the genetic backgrounds of VRSA strains. The results of present study will help to more completely elucidate the current epidemiology of VRSA and will promote the more proper antimicrobial stewardship programs to combat, control, management and limit the development of these drug-resistant organisms.

\section{Methods \\ Guidelines}

This review is reported accordant with the Preferred Reporting Items for Systematic Reviews and Meta Analyses guidelines (PRISMA) [11].

\section{Search strategy}

Four bibliographic databases, including international databases (MEDLINE [PubMed], Scopus, Embase, and Web of Science) for relevant articles were searched (Until January 8, 2020) by using the following keywords: ("Staphylococcus aureus" OR "S. aureus" OR "Vancomycin Resistant Staphylococcus aureus" OR "Vancomycin Resistant S. aureus" OR "VRSA") in the Title/Abstract/
Keywords fields. No limitations were used while searching the databases. But inclusion in the study for full analysis required at least the abstract to be available in English. The search strategy was designed and conducted by study investigators (E.K, S.K and M.SH). The detailed search strategy and complete list of studies included in the study are shown in Additional file 1: Table. References lists of all related studies were also reviewed for any other related publication. The records found through database searching were merged and the duplicates were removed using EndNote X7 (Thomson Reuters, New York, NY, USA). One of the team researchers randomly evaluated the search results and confirmed that no relevant study had been ignored. All these steps were done by the three authors (M.SH) and any disagreements about article selection were resolved through discussion, and a fourth author (E.K) acted as arbiter.

\section{Inclusion and exclusion criteria}

Three reviewers (YW, E.K, and QW) screened all titles and abstracts independently and excluded irrelevant or duplicate articles first. Three reviewers then independently assessed the remaining articles for inclusion. Discrepancies were resolved by discussion. Identified studies, met the criteria of being original articles published in English, and concerning the prevalence of VRSA based on different years, areas, isolate source, antimicrobial susceptibility testing, and the genetic determinants. The exclusion criteria were as follows: (1) studies that contained duplicate data or were overlapping articles; (2) reviews, meta-analysis and/or systematic review, and conference abstracts or article without full text; and (3) VRSA rate was not presented or clearly reported; (4) articles that included fewer than $10 \mathrm{~S}$. aureus isolates.

\section{Data extraction}

The following items were extracted from each included study: the last name of the first author, year of study, year published, continent, country, number of tested $S$. aureus, sample source, isolates number of VRSA, phenotypic and genotypic methods used, and the genetic determinants associated with VRSA isolates. Data were collected by two independent examiners and verified by another researcher (Additional file 1: Table).

\section{Assessment of study quality}

The quality of the included studies was assessed by 2 reviewers (N.S and M.H) independently using an adapted version of the tool proposed by the Newcastle-Ottawa assessment scale adapted for cross-sectional studies [12]. A score ranging from 0 to 7 points was attributed to each study ( $\geq 6$ points: high quality, $\leq 5$ points: low quality). A higher score indicated a higher study quality. A third 
reviewer (E.K) adjudicated in any cases where there was disagreement.

\section{Study outcomes}

The main outcome of interest was the weighted pooled resistance rate (WPR) of strains resistant to vancomycin. A subgroup analysis was performed; (1) subgroup analyses were then employed by publication date $(<2006$, 2006-2014, and 2015-2020), (2) geographic areas (continent/countries), (3) antimicrobial susceptibility testing, (4) quality of studies, (5) isolate source, and (6) the genetic determinants associated with VRSA.

\section{Risk of bias within studies}

Publication bias was analysed using Egger's linear regression test.

\section{Statistical analysis}

Cross-sectional studies presenting raw data on VRSA were included in the meta-analysis that was performed by computing the pooled using a random- effects model with Stata/SE software, v.14.1 (StataCorp, College Station, TX). The inconsistency across studies was examined by the forest plot as well as the $\mathrm{I}^{2}$ statistic. Values of $\mathrm{I}^{2}(25 \%, 50 \%$ and $75 \%)$ were interpreted as the presence of low, medium, or high heterogeneity, respectively. So, the DerSimonian and Laird random effects models were used [13]. Subgroup analyses were then employed by publication year, geographic areas (continent/countries), antimicrobial susceptibility testing, quality of studies, isolate source and the genetic determinants associated with VRSA. Publication bias was assessed using Egger's test. All statistical interpretations were reported on a $95 \%$ confidence interval (CI) basis.

\section{Results}

\section{Study selection}

A total of 2750 records were identified in the initial search. From these, 2565 articles were excluded after an initial screening of the title and abstract due to their irrelevance and duplication. The full texts of the remaining 185 articles were reviewed (Fig. 1).

\section{Study characteristics}

From the 185 articles, 102 were excluded for the following reasons: meta-analysis, review, conference abstract and article without full text $(\mathrm{n}=66)$, and non-relevant data or no data for VRSA $(\mathrm{n}=36)$. Eighty-three studies included in qualitative synthesis (62 cross-sectional studies and 21 case reports) (Additional file 1: Table; Additional file 2: Figure S1). Finally, 62 cross-sectional studies [14-75] were included in this meta-analysis.

\section{Risk of bias within studies}

Publication bias was assessed for 62 studies (Additional file 2: Figure $\mathrm{S} 1$ ). The analysis displayed visual asymmetry of the funnel plot and a significant Egger's test $(P<0.05)$.

\section{Characteristics of included studies}

The 62 studies included [14-75] in the analysis investigated 807 VRSA isolates from 12,816 S. aureus isolates. Among the 62 studies included, 25 cross-sectional studies also investigated 367 VRSA isolates from 3925 MRSA isolates (Table 1). All 62 studies had a cross-sectional design. The quality of data was high in $43(69.3 \%)$ studies and low in 19 (30.7\%) studies. The forest plots that show the analyses for overall VRSA and subgroups are displayed in the Additional file 3: Figure S2. In addition, twenty-one case-reports [76-96] included in qualitative synthesis (which were not taken into account during the meta-analysis) that reported 29 VRSA isolates between 1999 to 2019 among different continents (Additional file 1: Table). However, most case reports have been from America ( $\mathrm{n}=14$ isolates) and Asia ( $\mathrm{n}=11$ isolates) continents. There has been no report of VRSA isolates in Oceania.

\section{The prevalence of VRSA in three study periods}

To analyze the trends for changes in the prevalence of VRSA in more recent years, we performed a subgroup analysis for three periods ( $<2006,2006-2014$, and 20152020) (Table 2, Fig. 2). As shown in the Table 2, the prevalence of VRSA gradually increased from $2 \%$ (95\% CI 0-4) of 466 strains before 2006 to 6\% (95\% CI 3-9) of 6692 strains in 2006-2014, reaching 7\% (95\% CI 4-11) of 5798 strains in 2015-2020. Thus, the frequency of VRSA during the years 2006-2014 represents a threefold increase over the years before 2006. Additionally, the frequency of VRSA during the years 2015-2020 represents a $\sim 1.2$ fold increase over the years before 2015. The changes in VRSA and VRSA from MRSA prevalence between periods are showed in Fig. 2. The prevalence of VRSA from MRSA gradually increased from $1 \%(95 \%$ CI $0-5)$ before 2006 to $5 \%$ (95\% CI 0-14) in 2006-2014, reaching 6\% (95\% CI 0-10) in 2015-2020.

\section{Prevalence of VRSA at different locations}

The prevalence of VRSA differed among geographic regions in the subgroup analysis, as shown in Table 1 and Figs. 3, 4, 5. The prevalence of VRSA was 5\% (95\% CI 3-8) among 11,074 S. aureus isolates in Asia, 1\% (95\% CI $0-5)$ among $456 \mathrm{~S}$. aureus isolates in Europe, 4\% (95\% CI $2-7)$ among 395 isolates in America, 3\% (95\% CI 0-17) among 171 isolates in South America and 16 (95\% CI 3-35) among 720 isolates in Africa. There has been no 

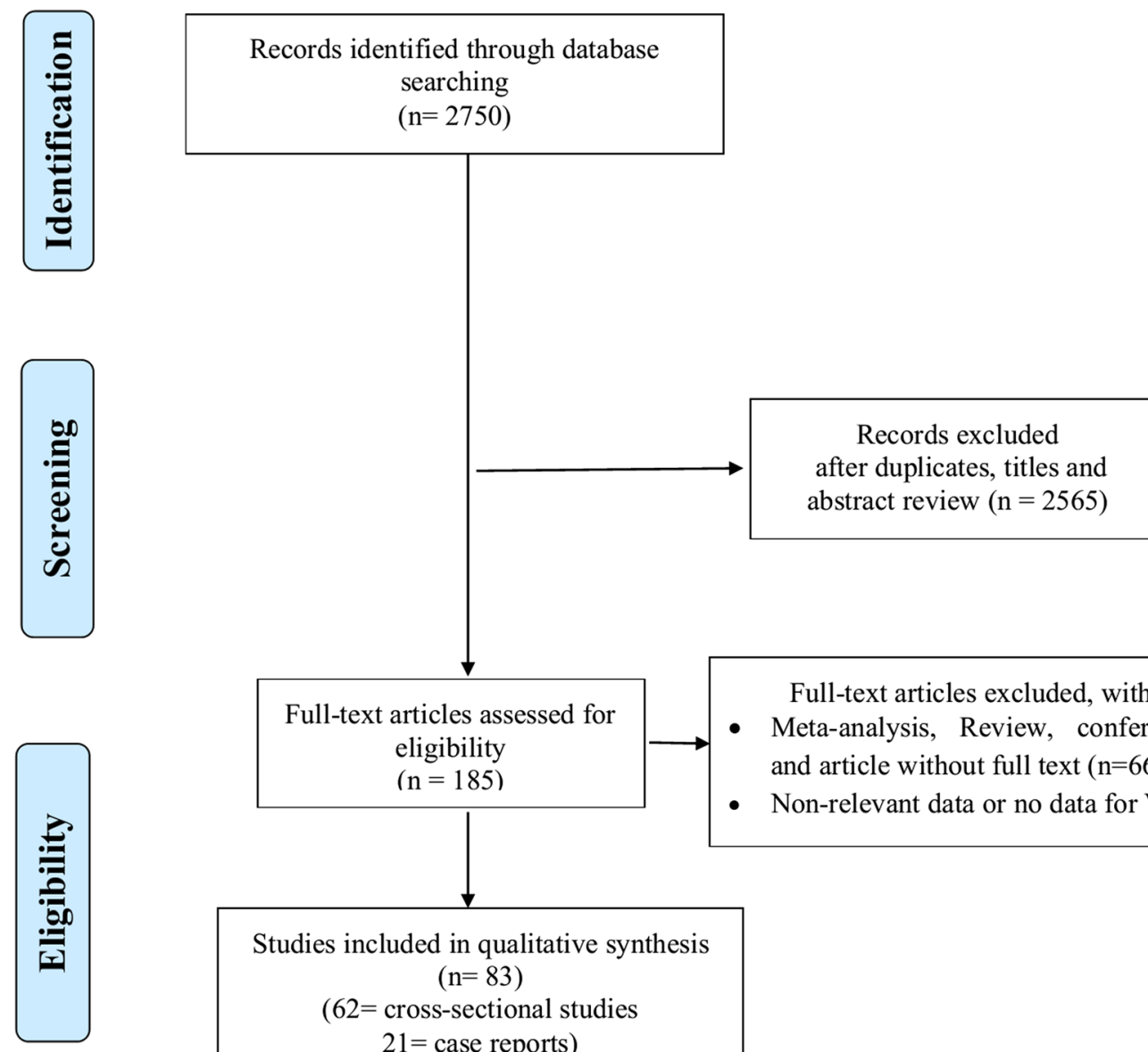

Full-text articles assessed for eligibility $(\mathrm{n}=185)$

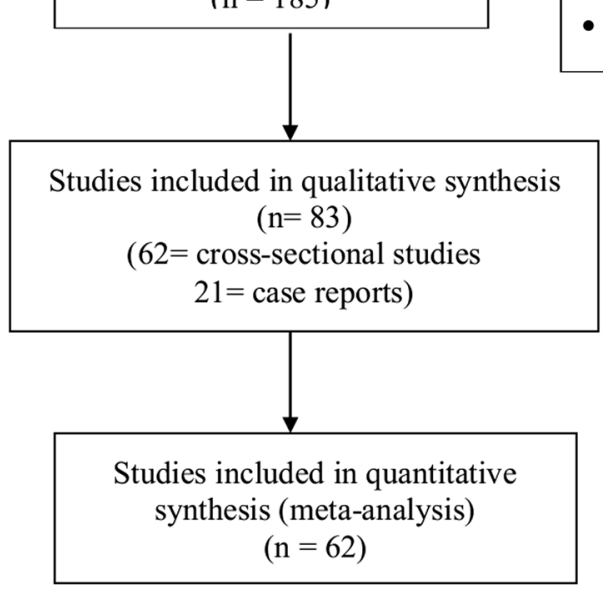

Full-text articles excluded, with reasons;

- Meta-analysis, Review, conference abstract and article without full text $(n=66)$

- Non-relevant data or no data for VRSA $(n=36)$

Fig. 1 Flow diagram showing the study selection process

report of VRSA from Oceania. The most frequent VRSA prevalence was $29 \%$ (95\% CI 24-35) in Nigeria, followed by $18 \%(95 \%$ CI 12-26) in Saudi Arabia (Table 1 and Figs. 4, 5).

\section{Prevalence of VRSA based on different clinical samples}

In this subgroup analysis, we divided the VRSA strains into three groups (clinical, non-clinical, and both of them). In total, the frequency of VRSA was $14 \%$ (95\% CI $0-44)$ in $501 \mathrm{~S}$. aureus strains isolated from mixed (clinical, non-clinical) samples in four studies, higher than in the clinical samples in (6\% [95\% CI 4-8] in 11,891 S. aureus strains in 53 studies) (Table 1). The prevalence rate for VRSA was 7\% (95\% CI 1-15) in 424 non-clinical S. aureus strains in six studies.

\section{Prevalence of VRSA based on AST methods}

Disk diffusion agar and Mixed-methods were the most frequent antimicrobial susceptibility testing method $(n=33)$, followed by MIC-base methods $(n=25)$. The prevalence of VRSA was $12 \%$ (95\% CI 2-27) among $6736 \mathrm{~S}$. aureus isolates using disk diffusion agar method, 7\% (95\% CI 4-12) among 5671 isolates using MIC-base methods, and 4 (95\% CI 2-7) among 6596 isolates using mixed-methods (Table 1). 
Table 1 Prevalence of VRSA in S. aureus and VRSA in MRSA based on quality, continent, countries, isolate source, and AST method

\begin{tabular}{|c|c|c|c|c|c|c|c|c|}
\hline Subject & Sub group & No. studies & No. strains & Proportion $(95 \% \mathrm{Cl})$ & \%Weight & $\mathbf{P}$ & $I^{2}$ & P sig \\
\hline \multirow[t]{2}{*}{ Overall } & VRSA & 62 & 12,816 & $0.06(0.04,0.09)$ & 100 & 0 & 0.9574 & 0 \\
\hline & VRSA from MRSA & 25 & 3925 & $0.06(0.03,0.09)$ & 100 & 0 & 0.9366 & 0 \\
\hline \multicolumn{9}{|l|}{ Quality } \\
\hline \multirow[t]{2}{*}{ High quality } & VRSA & 43 & 10,990 & $0.05(0.03,0.07)$ & 70.83 & 0 & 0.9599 & 0 \\
\hline & VRSA from MRSA & 19 & 3390 & $0.07(0.03,0.12)$ & 68.85 & 0 & 0.9531 & 0 \\
\hline \multirow[t]{2}{*}{ Low quality } & VRSA & 19 & 1826 & $0.1(0.04,0.17)$ & 28.68 & 0 & 0.9460 & 0 \\
\hline & VRSA from MRSA & 9 & 675 & $0.02(0.01,0.05)$ & 31.15 & 0.03 & 0.5328 & 0 \\
\hline \multicolumn{9}{|l|}{ Continent } \\
\hline \multirow[t]{2}{*}{ Asia } & VRSA & 46 & 11,074 & $0.05(0.03,0.08)$ & 75.03 & 0 & 0.9555 & 0 \\
\hline & VRSA from MRSA & 22 & 3416 & $0.06(0.03,0.11)$ & 82.07 & 0 & 0.9443 & 0 \\
\hline \multirow[t]{2}{*}{ South America } & VRSA & 2 & 171 & $0.03(0.00,0.17)$ & 1.39 & & & 0.16 \\
\hline & VRSA from MRSA & & - & & & & & \\
\hline \multirow[t]{2}{*}{ Africa } & VRSA & 7 & 720 & $0.16(0.03,0.35)$ & 11.20 & 0 & 0.9706 & 0 \\
\hline & VRSA from MRSA & 1 & 50 & $0.00(0.00,0.07)$ & 3.06 & & & 0 \\
\hline \multirow[t]{2}{*}{ America } & VRSA & 3 & 395 & $0.04(0.02,0.07)$ & 6.48 & 0.23 & 0.3054 & 0 \\
\hline & VRSA from MRSA & 2 & 272 & $5(0.03,0.08)$ & 8.08 & & & 1 \\
\hline \multirow[t]{2}{*}{ Europe } & VRSA & 4 & 456 & $0.01(0,0.05)$ & 5.90 & 0.03 & 0.6616 & 0.14 \\
\hline & VRSA from MRSA & 2 & 187 & $0(0,0.02)$ & 6.19 & & & 0.87 \\
\hline \multicolumn{9}{|l|}{ Countries } \\
\hline \multirow[t]{2}{*}{ Pakistan } & VRSA & 5 & 934 & $0.1(0.01,0.24)$ & 8.40 & 0 & 0.9693 & 0.01 \\
\hline & VRSA from MRSA & 3 & 301 & $0.07(0,0.25)$ & 11.61 & & & 0.06 \\
\hline \multirow[t]{2}{*}{ India } & VRSA & 14 & 5647 & $0.07(0.03,0.13)$ & 23.42 & 0 & 0.9778 & 0 \\
\hline & VRSA from MRSA & 6 & 3529 & $0.06(0,0.18)$ & 23.50 & 0.01 & 0.98 & 0.03 \\
\hline \multirow[t]{2}{*}{ Brazil } & VRSA & 3 & 203 & $0.03(0.01,0.07)$ & 4.48 & 0.00 & 0 & 0 \\
\hline & VRSA from MRSA & 1 & 140 & $0.04(0.01,0.08)$ & 4.08 & & & 0 \\
\hline \multirow[t]{2}{*}{ Nigeria } & VRSA & 2 & 273 & $0.29(0.24,0.35)$ & 3.30 & & & 0 \\
\hline & VRSA from MRSA & - & & & & & & \\
\hline \multirow[t]{2}{*}{ Iran } & VRSA & 16 & 3464 & $0.02(0.01,0.04)$ & 26.28 & 0 & 0.7848 & 0 \\
\hline & VRSA from MRSA & 6 & 875 & $0.04(0.01,0.08)$ & 23.20 & 0.01 & 67.03 & \\
\hline \multirow[t]{2}{*}{ Algeria } & VRSA & 3 & 583 & $0.01(0,0.04)$ & 1.72 & & & 0.01 \\
\hline & VRSA from MRSA & 1 & 220 & $0.02(0,0.05)$ & 4.08 & & & 0.01 \\
\hline \multirow[t]{2}{*}{ USA } & VRSA & 2 & 363 & $0.04(0.02,0.07)$ & 3.39 & & & 0 \\
\hline & VRSA from MRSA & 1 & 132 & $0.08(0.04,0.13)$ & 3.66 & & & 0 \\
\hline \multirow[t]{2}{*}{ Italy } & VRSA & 3 & 448 & $0.02(0,0.05)$ & 5.03 & & & 0.02 \\
\hline & VRSA from MRSA & 1 & 179 & $0.01(0,0.04)$ & 4.10 & & & 0.03 \\
\hline \multirow[t]{2}{*}{ Saudi Arabia } & VRSA & 2 & 128 & $0.18(0.12,0.26)$ & 3.02 & & & 0 \\
\hline & VRSA from MRSA & 1 & 98 & $0.15(0.09,0.24)$ & 3.95 & & & 0 \\
\hline Tanzania & VRSA & 1 & 53 & $0.11(0.04,0.23)$ & 1.53 & & & 0 \\
\hline & VRSA from MRSA & - & - & $(.)$. & & & & \\
\hline Egypt & VRSA & 4 & 394 & $0.16(0.01,0.45)$ & 6.36 & 0 & 0.9719 & 0.02 \\
\hline & VRSA from MRSA & 1 & 50 & $0(0,0.07)$ & 3.66 & & & 1 \\
\hline Turkey & VRSA & 5 & 469 & $0.05(0,0.14)$ & 7.65 & 0 & 0.8895 & 0.02 \\
\hline & VRSA from MRSA & 3 & 245 & $0.04(0,0.13)$ & 9.56 & & & 0.1 \\
\hline Bangladesh & VRSA & 2 & 73 & $0.12(0.05,0.21)$ & 2.86 & & & 0 \\
\hline & VRSA from MRSA & 2 & 73 & $0.27(0.13,0.43)$ & 5.76 & & & 0 \\
\hline Germany & VRSA & 1 & 8 & $0.13(0,0.53)$ & 0.87 & & & 0.15 \\
\hline & VRSA from MRSA & 1 & 8 & $0.13(0,0.53)$ & 2.09 & & & 0.15 \\
\hline Jordan & VRSA & 1 & 139 & $0.04(0.01,0.08)$ & 1.68 & & & 0 \\
\hline & VRSA from MRSA & - & - &.$(.)$. & & & & \\
\hline
\end{tabular}


Table 1 (continued)

\begin{tabular}{|c|c|c|c|c|c|c|c|c|}
\hline Subject & Sub group & No. studies & No. strains & Proportion $(95 \% \mathrm{Cl})$ & \%Weight & $\mathbf{P}$ & $1^{2}$ & P sig \\
\hline \multicolumn{9}{|l|}{ Isolate source } \\
\hline \multirow[t]{2}{*}{ Clinical } & VRSA & 53 & 11,891 & $0.06(0.04,0.08)$ & 84.56 & 0 & 0.9582 & 0 \\
\hline & VRSA from MRSA & 23 & 5779 & $0.06(0.03,0.10)$ & 85.92 & 0 & 0.9420 & 0 \\
\hline \multirow[t]{2}{*}{ Clinical, non-clinic } & VRSA & 4 & 501 & $0.14(0.00,0.44)$ & 06.54 & 0 & 0.9815 & 0.04 \\
\hline & VRSA from MRSA & 1 & 179 & $0.01(0.00,0.04)$ & 04.10 & & & 0.03 \\
\hline \multirow[t]{2}{*}{ Non-clinical } & VRSA & 6 & 424 & $0.07(0.01,0.15)$ & 8.91 & 0 & 0.8615 & 0 \\
\hline & VRSA from MRSA & 3 & 245 & $0.04(0.00,0.13)$ & 9.98 & & & 0.10 \\
\hline \multicolumn{9}{|l|}{ AST method(s) } \\
\hline \multirow[t]{2}{*}{ MIC-base } & VRSA & 25 & 5671 & $0.07(0.04,0.12)$ & 39.87 & 0 & 0.9599 & 0 \\
\hline & VRSA from MRSA & 9 & 1223 & $0.09(0.03,0.17)$ & 30.99 & 0 & 0.874 & 0 \\
\hline \multirow[t]{2}{*}{ Mixed-methods } & VRSA & 32 & 6596 & $0.04(0.02,0.07)$ & 51.95 & 0 & 0.9527 & 0 \\
\hline & VRSA from MRSA & 17 & 4995 & $0.04(0.01,0.09)$ & 64.48 & 0 & 0.9538 & 0 \\
\hline \multirow[t]{2}{*}{ Disk diffusion } & VRSA & 33 & 6736 & $0.12(0.02,0.27)$ & 8.18 & 0 & 0.9532 & 0 \\
\hline & VRSA from MRSA & 1 & 85 & $0.05(0.01,0.17)$ & 3.52 & & & 0.03 \\
\hline
\end{tabular}

$I^{2}$ : the percentage of variance in a meta-analysis that shows study heterogeneity. VRSA: Vancomycin-resistant Staphylococcus aureus. MRSA: Methicillin-resistant Staphylococcus aureus. AST: Antimicrobial Susceptibility Testing. MIC: minimum inhibitory concentration

Table 2 Prevalence of VRSA in S. aureus and VRSA in MRSA based on year published

\begin{tabular}{|c|c|c|c|c|c|c|c|c|}
\hline Subject & Sub group & No. studies & No. strains & Proportion $(95 \% \mathrm{Cl})$ & \%Weight & $\mathbf{P}$ & $I^{2}$ & P sig \\
\hline \multirow[t]{2}{*}{ 2015-2020 } & VRSA & 31 & 5798 & $0.07(0.04,0.11)$ & 54.71 & 0 & 0.9579 & 0 \\
\hline & VRSA from MRSA & 16 & 1608 & $0.06(0.03,0.10)$ & 61.54 & 0 & 0.8246 & 0 \\
\hline \multirow[t]{2}{*}{ 2006-2014 } & VRSA & 28 & 6692 & $0.06(0.03,0.09)$ & 39.35 & 0 & 0.9620 & 0 \\
\hline & VRSA from MRSA & 9 & 4408 & $0.05(0.00,0.14)$ & 28.22 & 0 & 0.9771 & 0.01 \\
\hline \multirow[t]{2}{*}{$<2006$} & VRSA & 4 & 466 & $0.02(0,0.04)$ & 5.93 & 0.17 & 0.3949 & 0.01 \\
\hline & VRSA from MRSA & 3 & 327 & $0.01(0,0.05)$ & 10.24 & - & - & 0.15 \\
\hline
\end{tabular}

$\mathrm{I}^{2}$ : the percentage of variance in a meta-analysis that shows study heterogeneity. VRSA Vancomycin-resistant Staphylococcus aureus, MRSA Methicillin-resistant Staphylococcus aureus

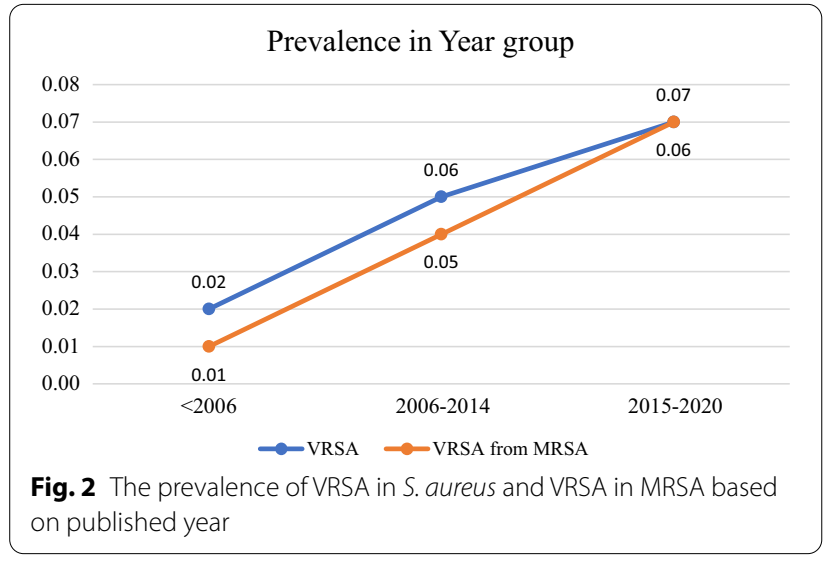

Prevalence of genetic determinants associated with VRSA The prevalence of $v a n A, v a n B$, and $v a n C 1$ positive were $\% 71$ (95\% CI $48-89)$, $26 \%$ (95\% CI 5-52), and 4\% (95\%

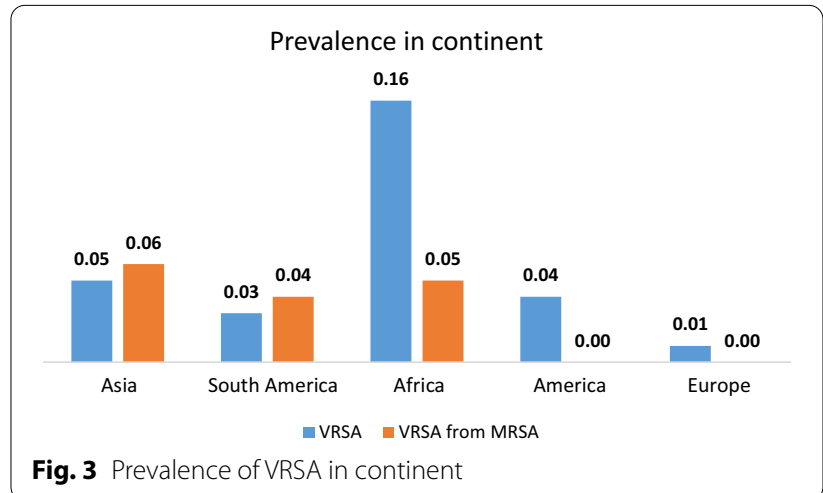

CI $0-55$ ) among 250, 75, and 9 of the $S$. aureus strains, respectively (Table 3 ). The prevalence of SCCmec II, SCCmec III, and SCCmec IV were 57\% (95\% CI 33-8), $17 \%$ (95\% CI 1-43), and 39\% (95\% CI 14-67) among the S. aureus strains, respectively (Table 3 ). 

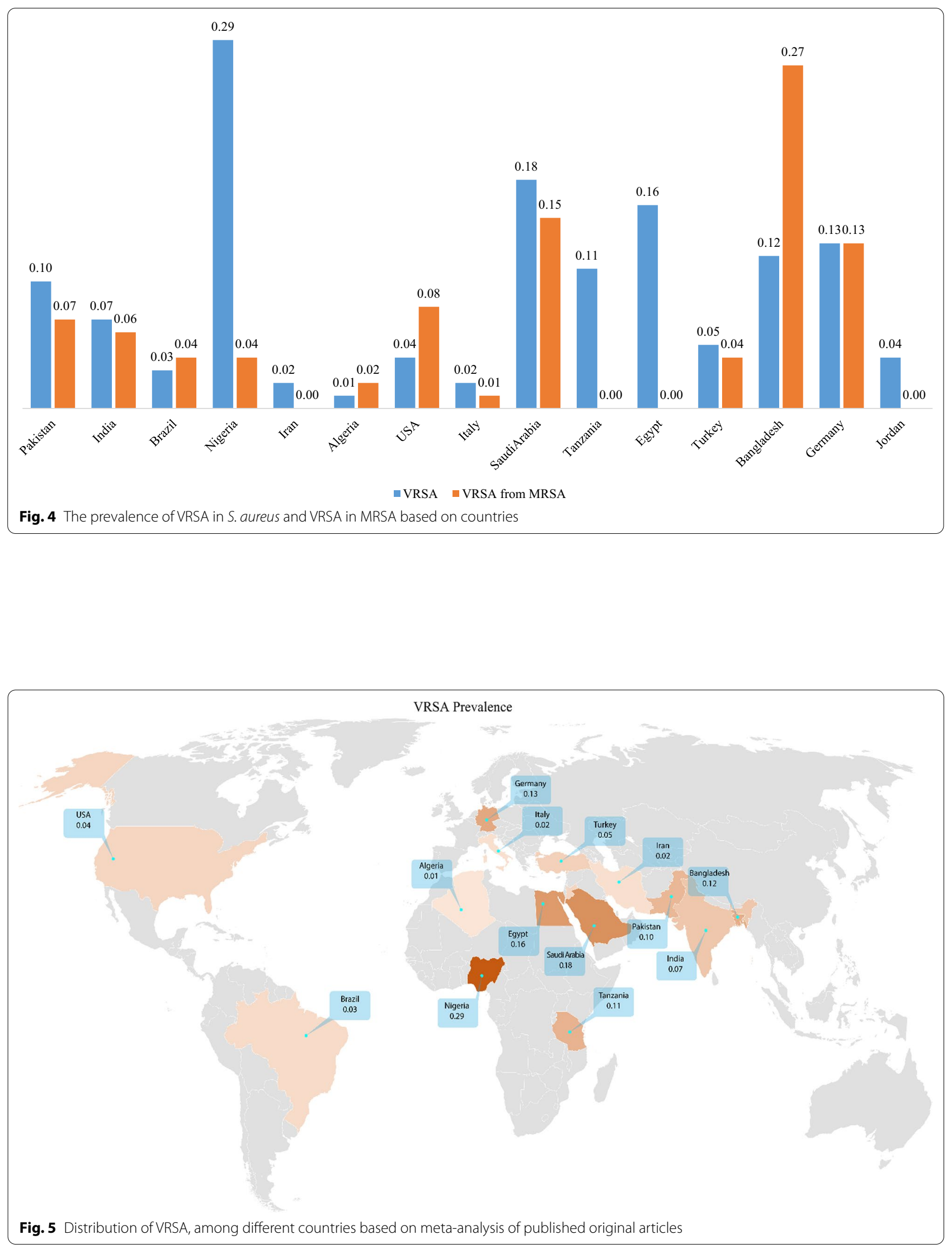
Table 3 Prevalence of genetic determinants associated with VRSA

\begin{tabular}{|c|c|c|c|c|c|c|c|c|}
\hline Subject & Sub group & No. studies & No. strains & Proportion $(95 \% \mathrm{Cl})$ & \%Weight & $\mathbf{P}$ & $1^{2}$ & P sig \\
\hline $\operatorname{vanA}$ & VRSA & 34 & 181 & $0.71(0.48,0.89)$ & 100 & 0 & 0.8515 & 0 \\
\hline $\operatorname{vanB}$ & VRSA & 16 & 20 & $0.26(0.05,0.52)$ & 100 & 0 & 0.6002 & 0 \\
\hline $\operatorname{vanC1}$ & VRSA & 4 & 1 & $0.04(0,0.55)$ & 100 & 0.21 & 0.3341 & 0.63 \\
\hline sccmec II & VRSA & 4 & 13 & $0.57(0.33,0.8)$ & 100 & 0.58 & 0 & 0 \\
\hline sccmec III & VRSA & 2 & 3 & $0.17(0.01,0.43)$ & 100 & - & - & 0.02 \\
\hline scCmec IV & VRSA & 6 & 14 & $0.39(0.14,0.67)$ & 100 & 0.1 & 0.4635 & 0 \\
\hline
\end{tabular}

$\mathrm{I}^{2}$ : the percentage of variance in a meta-analysis that shows study heterogeneity. VRSA: Vancomycin-resistant Staphylococcus aureus. MRSA: Methicillin-resistant Staphylococcus aureus

\section{Discussion}

The MRSA infections are the major clinical, public health, and economic challenges and also because concerns associated to inadequate dosing, poor tissue penetration of the drug and antimicrobial resistance is dramatically associated with the limited number of antimicrobials that can be used for the treatment of MRSA infections since they remain a significant cause of mortality $[97,98]$. The vancomycin has been considered as the last resort for the treatment of MRSA infections [7]. Increasingly, literature have reported the vancomycin treatment failure [99-101]. Our meta-analysis reports the prevalence of VRSA worldwide. In 62 studies (including 12,816 strains) chosen for our analysis, the global prevalence of VRSA was only $6 \%$. Thus, we think that the incidence of VRSA was underestimated, probably because of the resistance mechanisms and biological features of VRSA strains. By the way, VRSA tends to be MDR against a diversity of currently available antibiotics including $\beta$-lactams, have been found from livestock farming that emphasizes the over-use and misuse of antibiotics in animals [102-104].

To analyze the trends in the prevalence of VRSA in more recent years, we allotted the study published into three periods: before 2006, 2006-2014, and 2015-2020. Our study suggests that the prevalence of VRSA has been increasing in recent years. A threefold increase was found in the frequency of VRSA between before 2006 to 2006-2014 and 1.2-fold increase between 2006-2014 and 2015-2020. In recent years, the possible purposes for the emergence or detecting more VRSA strains include: most frequent administration of vancomycin for treatment of MRSA infections, improved diagnostics, inadequate monitoring of definite antibiotic policy, insufficient surveillance for vancomycin-resistance and the change in the vancomycin-resistance breakpoints since 2006 [105-107].

The incidence rates of VRSA strains have diverse all over the world: the occurrence of VRSA was $16 \%$ in Africa, 5\% in Asia and 1\% in Europe, 4\% in North America, and 3\% in South America.
Furthermore, 773 strains of VRSA were found in Africa/Asia versus 34 VRSA in Europe/America. The proposition that VRSA is more prevalent in African/ Asian countries than in Europe/America. There are numerous reasons including; the high public hygiene standards, careful consideration of current antimicrobial treatments and the more successful monitoring of nosocomial-associated infections in most of developed countries $[108,109]$ may account in the lower prevalence of VRSA in developed, in comparison to developing countries. However, the lack of testing in many situations in developing countries due to limited resources, may lead to the false impression of higher VRSA prevalence as the total number tested is not the true number of $S$. aureus infections.

The most reports (46 reports) of VRSA were from Asia (particularly from Iran [16 reports] and India [14 reports]) was higher than on the other continents. On the other hand, it should be mentioned that 56.8\% (459/807) of VRSA strains were reported from Iran and India. Thus, our meta-analysis displays that the Asian data are biased towards Iran and India. Current evidence of VRSA in India and Iran supports rigorous monitoring of definite antibiotic policy, and active surveillance of nosocomialassociated infections. Furthermore, there is an alarm for the high prevalence of VRSA strains in Nigeria (29\%) and Saudi Arabia (18\%).

The clinical laboratories have the important role in the diagnosis of VRSA cases to warrant rapid recognition, isolation, and monitoring by infection control personnel [110]. Several methods can be used to determine the susceptibility of $S$. aureus isolates to vancomycin. The vancomycin resistance rates differ significantly when comparing the disk diffusion and MIC tests (threefold; $12 \% / 4 \%$ ). Disk diffusion is unreliable and does not differentiate between wild type isolates and those with nonvanA-mediated glycopeptide resistance [111, 112]. The MIC tests method is considered the gold standard technique for determining the susceptibility of $S$. aureus isolates to vancomycin $[111,112]$. However, these tests are 
time-consuming, laborious, and inappropriate for clinical laboratories specially in developing countries, so it may be some number of VRSA strains may have been missed.

Up to now, the genetic backgrounds associated with VRSA is clear, and also a molecular biological method to detect VRSA strains is available. In cross-sectional studies indicated in Table 3, the occurrence of mobile vancomycin-resistance genes; vanA and $v a n B$ in VRSA strains by PCR showed that $71 \%$ and $26 \%$ of the VRSA strains were $\operatorname{van} A$ and $\operatorname{van} B$ positive. This relative high rate of $v a n A$ and $v a n B$ in VRSA strains suggests the high potential of horizontal gene transfer of resistance determinants associated with VRSA from a vancomycin-resistant Enterococcus species or from one of the other $v a n A$ positive bacteria $[113,114]$. In the other VRSA isolates did not detect $v a n A$ and $v a n B$ suggests that possibly decreased permeability, thickened and poorly cross-linked cell wall may be responsible for the increase of vancomycin resistance in VRSA isolates. Additionally, numerous studies did not detect vanC1 gene. It has been demonstrated that SCCmec IV and V are prevalent in community-associated MRSA strains while SCCmec I, II, and III are the most common in hospital-acquired MRSA strains[115, 116]. The results of our analysis display that SCCmec II and $\mathrm{V}$ were the most frequent molecular types associated with VRSA strains. It has been showed a partial vancomycin resistance potential in SCCmec IV MRSA clones $[117,118]$. However, we found that the high prevalence of SCCmec IV in VRSA strains suggesting that VRSA is not considered to classic hospital clones of $S$. aureus. Han et al. [119] displayed that the reduced vancomycin susceptibility was lower in SCCmec IV MRSA than SCCmec II MRSA isolates, in concordance with our metaanalysis. The Centers for Disease Control and Prevention (CDC) [110] has issued the risk factors that may involve to VRSA emergence including: prior MRSA and enterococcal infections or colonization, underlying conditions (such as chronic skin ulcers and diabetes), and previous treatment with vancomycin. Infection control precautions should remain in place until a defined endpoint has been determined in consultation with public health authorities. The current study had some limitations were including genetic determinants associated with VRSA was presented in $54.8 \%(34 / 62)$ of the studied articles. In addition, more than half $(56.8 \%$; 459/807) of VRSA strains were described from Iran and India. Therefore, our meta-analysis shows that the Asian data are biased towards Iran and India.

\section{Conclusions}

The prevalence of VRSA has been increasing in recent years particularly in Africa/Asia than Europe/America. The most prevalent of genetic determinants associated with
VRSA were vanA and SCCmec II. We found that VRSA is not considered only to classic hospital clones of $S$. aureus. Carful antimicrobial treatments by healthcare providers, adherence to recommended infection control recommendations, and, finally, the control of both MRSA and VRE are needed for preventing further emergence and dissemination of VRSA strains.

\section{Supplementary Information}

The online version contains supplementary material available at https://doi. org/10.1186/s13756-021-00967-y.

Additional file 1: Table. Characteristics of the eligible cross-sectional studies.

Additional file 2: Fig. S1. Funnel plot of the meta-analysis on overall vancomycin-resistant $S$. aureus in 62 studies included.

Additional file 3: Fig. S2. Detailed forrest plots of the meta-analysis

\section{Acknowledgements \\ None.}

Authors' contributions

$\mathrm{NS}, \mathrm{MH}, \mathrm{SK}, \mathrm{MSH}, \mathrm{QW}$ contributed to the conception, design, drafting of the work. EK, YW, QW contributed in revising and final approval of the version to be published. All authors read and approved the final manuscript.

\section{Funding}

None.

Availability of data and materials

All the data in this review are included in the manuscript.

\section{Declarations}

Ethical approval

Not applicable in this section.

Informed consent

Not applicable in this section.

Competing interests

The authors declare that they have no competing interests.

\section{Author details}

${ }^{1}$ The Medical Lab of Hainan Cancer Hospital, Hainan Province, Haikou 570312, People's Republic of China. ${ }^{2}$ Department of Microbiology, School of Medicine, Shahid Sadoughi University of Medical Sciences, Yazd, Iran. ${ }^{3}$ School of International Pharmaceutical Business, China Pharmaceutical University, Jiangsu Province, Nanjing 211198, People's Republic of China. ${ }^{4}$ Clinical Microbiology Research Center, Ilam University of Medical Sciences, Ilam, Iran. ${ }^{5}$ Laboratory Sciences Research Center, Golestan University of Medical Sciences, Gorgan, Iran. ${ }^{6}$ Department of Laboratory Sciences, Faculty of Paramedicine, Golestan University of Medical Sciences, Gorgan, Iran.

Received: 24 December 2020 Accepted: 3 June 2021

Published online: 30 June 2021

\section{References}

1. Cong Y, Yang S, Rao X. Vancomycin resistant Staphylococcus aureus infections: a review of case updating and clinical features. J Adv Res. 2020;21:169-76. https://doi.org/10.1016/j.jare.2019.10.005. 
2. Abbasian S, Farahani NN, Mir Z, Alinejad F, Haeili M, Dahmardehei M, Mirzaii M, Khoramrooz SS, Nasiri MJ, Darban-Sarokhalil D. Genotypic characterization of Staphylococcus aureus isolated from a burn centre by using agr, spa and SCCmec typing methods. New Microbes New Infect. 2018;26:15-9.

3. Amini A, AsgharAyatollahi A, Ghaemi EA, Rahimi S, Koohsar F, Kazemi R, Kouhsari E, Roustaei M. Comparison of ferment sugars, produce hemolysis and measuring growth in methicillin-resistant and methicillinsensitive Staphylococcus aureus isolates from inpatients and healthcare workers in Gorgan Hospitals, North of Iran. Biosci Biotechnol Res Asia. 2013;10(1):77-84.

4. Gajdács MJ. The continuing threat of methicillin-resistant Staphylococcus aureus. Antibiotics. 2019;8(2):52.

5. Purrello SM, Garau J, Giamarellos E, Mazzei T, Pea F, Soriano A, Stefani S. Methicillin-resistant Staphylococcus aureus infections: a review of the currently available treatment options. J Glob Antimicrob Resist. 2016;7:178-86. https://doi.org/10.1016/j.jgar.2016.07.010.

6. Khan A, Wilson B, Gould IM. Current and future treatment options for community-associated MRSA infection. Expert Opin Pharmacother. 2018;19(5):457-70. https://doi.org/10.1080/14656566.2018.1442826.

7. McGuinness WA, Malachowa N, DeLeo FR. Focus: infectious diseases: vancomycin resistance in Staphylococcus aureus. Yale J Biol Med. 2017:90(2):269.

8. Contol CfD Prevention. Staphylococcus aureus resistant to vancomycinUnited States, 2002. MMWR Morb Mortal Wkly Rep. 2002;51 (26):565.

9. Tenover FC, Biddle JW, Lancaster MV. Increasing resistance to vancomycin and other glycopeptides in Staphylococcus aureus. Emerging Infect Dis. 2001;7(2):327.

10. Shariati A, Dadashi M, Moghadam MT, van Belkum A, Yaslianifard S, Darban-Sarokhalil DJ. Global prevalence and distribution of vancomycin resistant, vancomycin intermediate and heterogeneously vancomycin intermediate Staphylococcus aureus clinical isolates: a systematic review and meta-analysis. Sci Rep. 2020;10(1):1-16.

11. Moher D, Liberati A, Tetzlaff J, Altman DG. Preferred reporting items for systematic reviews and meta-analyses: the PRISMA statement. PLoS Med. 2009:6(7):e1000097.

12. Modesti PA, Reboldi G, Cappuccio FP, Agyemang C, Remuzzi G, Rapi S, Perruolo E, Parati G, ESH Working Group on CV Risk in Low Resource Settings. Panethnic differences in blood pressure in Europe: a systematic review and meta-analysis. PLoS ONE. 2016;11(1):e0147601. https:// doi.org/10.1371/journal.pone.0147601.

13. DerSimonian R, Laird N. Meta-analysis in clinical trials. Control Clin Trials. 1986;7(3):177-88. https://doi.org/10.1016/0197-2456(86)90046-2.

14. Abd El-Aziz NK, Abd El-Hamid Ml, Bendary MM, El-Azazy AA, Ammar AMJ. Existence of vancomycin resistance among methicillin resistant S. aurues recovered from animal and human sources in Egypt. Slov Vet Res. 2018;55(Suppl 20):221-30.

15. AbdEl-Mongy M, Awad ET, Mosaed FJ. Vancomycin resistance among methicillin resistant Staphylococcus aureus isolates from neonatal sepsis attending intensive care unit in Shibin El-Kom Teaching Hospital, Egypt. J Pure Appl Microbiol. 2018;12(3):1093-100.

16. Akia A, Amini KJ. The prevalence of van gene alleles in clinical isolates of Staphylococcus aureus. Sci J Kurd Univ Med Sci. 2017;21(6):64-71.

17. Aligholi M, Emaneini M, Jabalameli F, Shahsavan S, Dabiri H, Sedaght H. Emergence of high-level vancomycin-resistant Staphylococcus aureus in the Imam Khomeini Hospital in Tehran. Med Princ Pract. 2008;17(5):432-4. https://doi.org/10.1159/000141513.

18. Alzolibani AA, Al Robaee AA, Al Shobaili HA, Bilal JA, Ahmad MI, Saif GBJ. Documentation of vancomycin-resistant Staphylococcus aureus (VRSA) among children with atopic dermatitis in the Qassim region, Saudi Arabia. Acta Dermatovenerol Alp Pannonica Adriat. 2012;21(3):51-3.

19. Anvari M, Ranji N, Khoshmaslak FJ. Antibacterial susceptibility of three vancomycin-resistant Staphylococcus aureus strain isolated from northern part of Iran. J Pure Appl Microbiol. 2012:6(2):671-5.

20. Arslan S, Ozkardes F. Slime production and antibiotic susceptibility in staphylococci isolated from clinical samples. Mem Inst Oswaldo Cruz. 2007;102(1):29-33. https://doi.org/10.1590/s0074-02762007000100004.

21. Asadpour L, Ghazanfari N. Detection of vancomycin nonsusceptible strains in clinical isolates of Staphylococcus aureus in northern Iran. Int Microbiol. 2019;22(4):411-7. https://doi.org/10.1007/ s10123-019-00063-7.
22. Azhar A, Rasool S, Haque A, Shan S, Saeed M, Ehsan B, Haque A. Detection of high levels of resistance to linezolid and vancomycin in Staphylococcus aureus. J Med Microbiol. 2017;66(9):1328-31. https://doi. org/10.1099/jmm.0.000566.

23. Bamigboye BT, Olowe OA, Taiwo SS. Phenotypic and molecular identification of vancomycin resistance in clinical Staphylococcus aureus isolates in Osogbo, Nigeria. Eur J Microbiol Immunol (Bp). 2018;8(1):25-30. https://doi.org/10.1556/1886.2018.00003.

24. Bataineh HA. Resistance of Staphyiococcus aureus to vancomycin in Zarqa, Jordan. Pak J Med Sci. 2006;22(2):144.

25. Bezerra Neto AM, Rabelo MA, Lima J, Loibman SO, Leal NC, Maciel MAV. Occurrence of the vanA gene in Staphylococcus epidermidis from nasopharyngeal secretion of Health-Care Workers, Recife, Brazil. Rev Soc Bras Med Trop. 2018;51(3):304-9. https://doi.org/10.1590/ 0037-8682-0159-2017.

26. Bhattacharya S, Bir R, Majumdar T. Evaluation of multidrug resistant Staphylococcus aureus and their association with biofilm production in a Tertiary Care Hospital, Tripura, Northeast India. J Clin Diagn Res. 2015;9(9):DC01.

27. Budati S, Murty SN, Kuncham R, Vijayaraghavan R, Rao BNJ. Studies on vanA gene loci among Methicillin Sensitive Staphylococcus aureus in rural and urban tertiary care centers. J Environ Biol. 2016;37(4):625.

28. Chaudhary M, Payasi AJ. Vancoplus kinetic study in vancomycin resistant Staphylococcus aureus. J Pharm Sci Rev Res. 2015;31:135-42.

29. Cui L, Hiramatsu K, Mamizuka EM. Isolation in Brazil of nosocomial Staphylococcus aureus with reduced susceptibility to vancomycin. Infect Control Hosp Epidemiol. 2001;22:443-8.

30. Dubey D, Rath S, Sahu MC, Pattnaik L, Debata NK, Padhy RN. Surveillance of infection status of drug resistant Staphylococcus aureus in an Indian teaching hospital. Asian Pac J Trop Dis. 2013;3(2):133-42.

31. Elal Mus T, Cetinkaya F, Karahan H, Gurbuz IB, Degirmenci G. Investigation of mecA gene, virulence traits and antibiotic resistance profiles in methicillin-resistant Staphylococcus aureus isolates from dairy products. J Food Saf. 2019;39(3):e12620.

32. ElSayed N, Ashour M, Amine AEK. Vancomycin resistance among Staphylococcus aureus isolates in a rural setting. Egypt Germs. 2018;8(3):134.

33. El-Zamkan MA, Mubarak AG, Ali AO. Prevalence and phylogenetic relationship among methicillin-and vancomycin-resistant Staphylococci isolated from hospital's dairy food, food handlers, and patients. Adv Vet Anim Res. 2019;6(4):463.

34. Fasihi Y, Kiaei S, Kalantar-Neyestanaki D. Characterization of SCCmec and spa types of methicillin-resistant Staphylococcus aureus isolates from health-care and community-acquired infections in Kerman, Iran. J Epidemiol Glob Health. 2017;7(4):263-7. https://doi.org/10.1016/j.jegh. 2017.08.004.

35. Fasihi Y, Saffari F, Mansouri S, Kalantar-Neyestanaki D. The emergence of vancomycin-resistant Staphylococcus aureus in an intensive care unit in Kerman, Iran. Wien Med Wochenschr. 2018;168(3-4):85-8. https://doi. org/10.1007/s10354-017-0562-6.

36. Fatima A, Shyum-Naqvi SB, Khaliq SA, Perveen S, Yousuf RI, Saeed R. Staphylococcal resistance against five groups of life saving antibiotics in the year 2003-2005. Pak J Pharm Sci. 2013;26(6):1137-40.

37. Fuchs PC, Kopp J, Häfner H, Kleiner U, Pallua N. MRSA-retrospective analysis of an outbreak in the burn centre Aachen. Burns. 2002;28(6):575-8.

38. Ghahremani M, Jazani NH, Sharifi Y. Emergence of vancomycin-intermediate and-resistant Staphylococcus aureus among methicillin-resistant $S$. aureus isolated from clinical specimens in the northwest of Iran. J Glob Antimicrob Resist. 2018;14:4-9.

39. Gohel K, Jojera A, Soni S, Gang S, Sabnis R, Desai M. Bacteriological profile and drug resistance patterns of blood culture isolates in a tertiary care nephrourology teaching institute. Biomed Res Int. 2014;2014: 153747. https://doi.org/10.1155/2014/153747.

40. Goud R, Gupta S, Neogi U, Agarwal D, Naidu K, Chalannavar R, Subhaschandra G. Community prevalence of methicillin and vancomycin resistant Staphylococcus aureus in and around Bangalore, southern India. Rev Soc Bras Med Trop. 2011;44(3):309-12. https://doi.org/10. 1590/s0037-86822011005000035.

41. Guran HS, Kahya S. Species diversity and pheno- and genotypic antibiotic resistance patterns of Staphylococci isolated from retail ground 
meats. J Food Sci. 2015;80(6):M1291-1298. https://doi.org/10.1111/ 1750-3841.12893.

42. Hadadi M, Heidari H, Ebrahim-Saraie HS, Motamedifar M. Molecular characterization of vancomycin, mupirocin and antiseptic resistant Staphylococcus aureus strains. Mediterr J Hematol Infect Dis. 2018;10(1):e2018053. https://doi.org/10.4084/MJHID.2018.053.

43. Hasan R, Acharjee M, Noor R. Prevalence of vancomycin resistant Staphylococcus aureus (VRSA) in methicillin resistant S. aureus (MRSA) strains isolated from burn wound infections. Ci Ji Yi Xue Za Zhi. 2016;28(2):49-53. https://doi.org/10.1016/j.tcmj.2016.03.002.

44. Hizlisoy H, Onmaz NE, Karadal F, Serhat A, Yildirim Y, Gonulalan Z, Kilic $H$. Antibiotic resistance gene profiles of Staphylococcus aureus isolated from foods of animal origin. Kafkas Univ Vet Fak Derg. 2018;24(2):243-9.

45. Icgen B. VanA-Type MRSA (VRSA) emerged in surface waters. Bull Environ Contam Toxicol. 2016;97(3):359-66. https://doi.org/10.1007/ s00128-016-1827-2.

46. Islam TAB, Shamsuzzaman S. Prevalence and antimicrobial susceptibility pattern of methicillin-resistant, vancomycin-resistant, and PantonValentine leukocidin positive Staphylococcus aureus in a tertiary care hospital Dhaka, Bangladesh. Tzu Chi Med. 2015;27(1):10-4.

47. Jahanshahi A, Zeighami H, Haghi F. Molecular characterization of methicillin and vancomycin resistant Staphylococcus aureus strains isolated from hospitalized patients. Microb Drug Resist. 2018;24(10):1529-36. https://doi.org/10.1089/mdr.2018.0069.

48. Khan MF, Patil S, Khan FA. Prevalence and drug resistance pattern of Staphylococcus aureus clinical isolates in Bastar region. J Clin Anal Med. 2015;6:628-32.

49. Kumar M. Multidrug-resistant Staphylococcus aureus, India, 2013-2015. Emerg Infect Dis. 2016;22:1666-7.

50. Liaqat F, Sheikh AA, Nazir J, Hussain T, Rabbani M, Shaheen AY, Muhammad J. Report-Isolation identification and control of vancomycin resistant Staphylococcus aureus. Pak J Pharm Sci. 2015;28(3):997-1004.

51. Marchese A, Balistreri G, Tonoli E, Debbia E, Schito G. Heterogeneous vancomycin resistance in methicillin-resistant Staphylococcus aureus strains isolated in a large Italian hospital. J Clin Microbiol. 2000;38(2):866-9.

52. Martins PD, de Almeida TT, Basso AP, de Moura TM, Frazzon J, Tondo EC, Frazzon AP. Coagulase-positive staphylococci isolated from chicken meat: pathogenic potential and vancomycin resistance. Foodborne Pathog Dis. 2013;10(9):771-6. https://doi.org/10.1089/fpd.2013.1492.

53. Mendem SK, Alasthimannahalli Gangadhara T, Shivannavar CT, Gaddad SM. Antibiotic resistance patterns of Staphylococcus aureus: a multi center study from India. Microb Pathog. 2016;98:167-70. https://doi. org/10.1016/.micpath.2016.07.010.

54. Mishra MP, Debata NK, Padhy RN. Surveillance of multidrug resistant uropathogenic bacteria in hospitalized patients in Indian. Asian Pac J Trop Biomed. 2013;3(4):315-24. https://doi.org/10.1016/S2221-1691(13) 60071-4.

55. Muneeri SS, Mobaiyen H, Mirzaie H. Study on Vancomycin-resistant staphylococcus aureus and identification of VanA gene in these strains isolated from Tabriz Shuhada Hospital using e-test and PCR methods. Life Sci. 2013;10(1):748-52.

56. Neel R. Multidrug resistance of isolates of methicillin resistant Staphylococcus aureus (MRSA) in paper currency notes from restaurants and hotels in Lusaka in Zambia. Int J Pharm Sci. 2012;5(1):363-6.

57. Olufunmiso O, Tolulope I, Roger C. Multidrug and vancomycin resistance among clinical isolates of Staphylococcus aureus from different teaching hospitals in Nigeria. Afr Health Sci. 2017;17(3):797-807.

58. Patted SM, Chinagudi S, Soragavi VR, Bhavi SB. The prevalence of MRSA infection in orthopaedic surgery in a Medical College Hospital: a 2-year analysis. Biomed Res. 2013;24(1):33-5.

59. Rebiahi SA, Abdelouahid DE, Rahmoun M, Abdelali S, Azzaoui H Emergence of vancomycin-resistant Staphylococcus aureus identified in the Tlemcen university hospital (North-West Algeria). Med Mal Infect. 2011:41(12):646-51. https://doi.org/10.1016/j.medmal.2011.09.010.

60. Saadat S, Solhjoo K, Norooz-Nejad M-J, Kazemi A. VanA and vanB positive vancomycin-resistant Staphylococcus aureus among clinical isolates in Shiraz, South of Iran. Oman Med J. 2014;29(5):335.

61. Saderi H, Oulia P, Shahrbanooie R. Vancomycin resistance among clinical isolates of Staphylococcus aureus. Arch Iran Med. 2005;8:100-3.
62. Saeed A, Ahsan F, Nawaz M, lqbal K, Rehman KU, ljaz T. Correction: Saeed, A., et al. Incidence of vancomycin-resistant phenotype of the methicillin-resistant Staphylococcus aureus isolated from a tertiary care hospital in Lahore. Antibiotics 2020, 9, 3. Antibiotics (Basel). 2020;9(2):3. https://doi.org/10.3390/antibiotics9020082.

63. Saravolatz LD, Pawlak J, Johnson LB. In vitro activity of oritavancin against community-associated meticillin-resistant Staphylococcus aureus (CA-MRSA), vancomycin-intermediate S. aureus (VISA), vancomycin-resistant S. aureus (VRSA) and daptomycin-non-susceptible S. aureus (DNSSA). Int J Antimicrob Agents. 2010;36(1):69-72.

64. Sharif MR, Alizargar J, Sharif A. Antibiotic susceptibility of Staphylococcus aureus in isolates of the patients with osteomyelitis. World J Med Sci. 2013:9(3):180-3.

65. Shekarabi M, Hajikhani B, Salimi Chirani A, Fazeli M, Goudarzi M. Molecular characterization of vancomycin-resistant Staphylococcus aureus strains isolated from clinical samples: a three year study in Tehran, Iran. PLoS ONE. 2017;12(8):e0183607. https://doi.org/10.1371/journal.pone. 0183607.

66. Sievert DM, Rudrik JT, Patel JB, McDonald LC, Wilkins MJ, Hageman JC. Vancomycin-resistant Staphylococcus aureus in the United States, 2002-2006. Clin Infect Dis. 2008;46(5):668-74.

67. Squeri R, Grillo OC, La Fauci V. Surveillance and evidence of contamination in hospital environment from meticillin and vancomycin-resistant microbial agents. J Prev Med Hyg. 2012;53(3):143-5.

68. Taj Y, Abdullah FE, Kazmi SU. Current pattern of antibiotic resistance in Staphylococcus aureus clinical isolates and the emergence of vancomycin resistance. J Coll Phys Surg Pak. 2010;20(11):728-32.

69. Talwar A, Saxena S, Kumar A, Kumar M, Kumar D. Vancomycin resistance among methicillin resistant Staphylococcus aureus isolates from Doon Valley hospitals. Uttarakhand Der Pharmacia Lettre. 2013;5(3):287-91.

70. Tascini C, Flammini S, Leonildi A, Ciullo I, Tagliaferri E, Menichetti F. Comparison of teicoplanin and vancomycin in vitro activity on clinical isolates of Staphylococcus aureus. J Chemother. 2012;24(4):187-90. https://doi.org/10.1179/1973947812Y.0000000026.

71. Thati V, Shivannavar CT, Gaddad SM. Vancomycin resistance among methicillin resistant Staphylococcus aureus isolates from intensive care units of tertiary care hospitals in Hyderabad. Indian J Med Res. 2011;134(5):704.

72. Tiwari HK, Sen MR. Emergence of vancomycin resistant Staphylococcus aureus (VRSA) from a tertiary care hospital from northern part of India. BMC Infect Dis. 2006;6(1):156. https://doi.org/10.1186/1471-2334-6-156.

73. Vellappally S, Divakar DD, Al Kheraif AA, Ramakrishnaiah R, Alqahtani A, Dalati MHN, Anil S, Khan AA, Harikrishna Varma PR. Occurrence of vancomycin-resistant Staphylococcus aureus in the oral cavity of patients with dental caries. Acta Microbiol Immunol Hung. 2017;64(3):343-51. https://doi.org/10.1556/030.64.2017.033.

74. Yousefi M, Fallah F, Arshadi M, Pourmand M, Hashemi A, Pourmand G. Identification of tigecycline-and vancomycin-resistant Staphylococcus aureus strains among patients with urinary tract infection in Iran. New Microbes New Infect. 2017;19:8-12.

75. Zadegan $\mathrm{H}$. The prevalence of methicillin and vancomycin resistant Staphylococcus aureus nasal carriage in large teaching hospital personnel. Afr J Microbiol Res. 2011;5(22):3716-9.

76. Azimian A, Havaei SA, Fazeli H, Naderi M, Ghazvini K, Samiee SM, Soleimani M, Peerayeh SN. Genetic characterization of a vancomycinresistant Staphylococcus aureus isolate from the respiratory tract of a patient in a university hospital in northeastern Iran. J Clin Microbiol. 2012;50(11):3581-5. https://doi.org/10.1128/JCM.01727-12.

77. Chang S, Sievert DM, Hageman JC, Boulton ML, Tenover FC, Downes FP, Shah S, Rudrik JT, Pupp GR, Brown WJ, Cardo D, Fridkin SK. Infection with vancomycin-resistant Staphylococcus aureus containing the vanA resistance gene. N Engl J Med. 2003;348(14):1342-7. https://doi.org/10. 1056/NEJMoa025025.

78. Miller D, Weltman A. Vancomycin-resistant Staphylococcus aureus-Pennsylvania, 2002. MMWR Morb Mortal Wkly Rep. 2002;51 (40):902.

79. Dedania VS, Hale BP, Bhatnagar P. Endogenous endophthalmitis due to clinically vancomycin-resistant Staphylococcus aureus. Retin Cases Br Rep. 2015;9(1):59-60.

80. Dezfulian A, Aslani MM, Oskoui M, Farrokh P, Azimirad M, Dabiri $H$, Salehian MT, Zali MR. Identification and characterization of a 
high vancomycin-resistant Staphylococcus aureus Harboring VanA gene cluster isolated from diabetic foot ulcer, Iran. J Basic Med Sci. 2012;15(2):803-6.

81. Emaneini M, Aligholi M, Hashemi FB, Jabalameli F, Shahsavan S, Dabiri $\mathrm{H}$, Jonaidi N, Dahi K. Isolation of vancomycin-resistant Staphylococcus aureus in a teaching hospital in Tehran. J Hosp Infect. 2007;66(1):92-3. https://doi.org/10.1016/j.jhin.2007.03.002.

82. Finks J, Wells E, Dyke TL, Husain N, Plizga L, Heddurshetti R, Wilkins M, Rudrik J, Hageman J, Patel J. Miller C (2009) Vancomycin-resistant Staphylococcus aureus, Michigan, USA. Emerg Infect Dis. 2007;15(6):9435. https://doi.org/10.3201/eid1506.081312.

83. Friães A, Resina C, Manuel V, Lito L, Ramirez M, Melo-Cristino J. Epidemiological survey of the first case of vancomycin-resistant Staphylococcus aureus infection in Europe. Epidemiol Infect. 2015;143(4):745-8.

84. Kaccia M, McDonald L. Vancomycin-resistant Staphylococcus aureusNew York. MMWR Morb Mortal Wkly Rep. 2004;53:322-3.

85. Limbago BM, Kallen AJ, Zhu W, Eggers P, McDougal LK, Albrecht VS. Report of the 13th vancomycin-resistant Staphylococcus aureus isolate from the United States. J Clin Microbiol. 2014;52(3):998-1002. https:// doi.org/10.1128/JCM.02187-13.

86. Melo-Cristino J, Resina C, Manuel V, Lito L, Ramirez M. First case of infection with vancomycin-resistant Staphylococcus aureus in Europe. Lancet. 2013;382(9888):205. https://doi.org/10.1016/S0140-6736(13)61219-2.

87. Moise PA, Schentag JJ. Vancomycin treatment failures in Staphylococcus aureus lower respiratory tract infections. Int I Antimicrob Agents. 2000;16(Suppl 1):S31-34. https://doi.org/10.1016/s0924-8579(00) 00303-4.

88. Okada N, Fujita T, Kanamori J, Sato A, Horikiri Y, Sato T, Fujiwara H, Daiko $H$. A case report of postoperative VRSA enteritis: effective management of rifampicin for vancomycin resistant Staphylococcus aureus enteritis after esophagectomy and colon reconstruction. Int I Surg Case Rep. 2018;52:75-8. https://doi.org/10.1016/j.ijscr.2018.08.038.

89. Panesso D, Planet PJ, Diaz L, Hugonnet JE, Tran TT, Narechania A, Munita JM, Rincon S, Carvajal LP, Reyes J, Londono A, Smith H, Sebra R, Deikus G, Weinstock GM, Murray BE, Rossi F, Arthur M, Arias CA. Methicillinsusceptible, vancomycin-resistant Staphylococcus aureus. Brazil Emerg Infect Dis. 2015;21(10):1844-8. https://doi.org/10.3201/eid2110.141914.

90. Rossi F, Diaz L, Wollam A, Panesso D, Zhou Y, Rincon S, Narechania A, Xing G, Di Gioia TS, Dsoi A, Tran TT, Reyes J, Munita JM, Carvajal LP, Hernandez-Roldan A, Brandao D, van der Heijden IM, Murray BE, Planet PJ, Weinstock GM, Arias CA. Transferable vancomycin resistance in a community-associated MRSA lineage. N Engl J Med. 2014;370(16):1524-31. https://doi.org/10.1056/NEJMoa1303359.

91. Sambandam SN, Rohinikumar GJ, Gul AM, Mounasamy V. Intramuscular injection abscess due to VRSA: a new health care challenge. ABJS 2016:4(3):277.

92. Sieradzki K, Roberts RB, Haber SW, Tomasz A. The development of vancomycin resistance in a patient with methicillin-resistant Staphylococcus aureus infection. N Engl J Med. 1999;340(7):517-23. https://doi.org/ 10.1056/NEJM199902183400704.

93. Stroh EM. Quinupristin/dalfopristin in vancomycin-resistant Staphy/ococcus aureus endophthalmitis. Arch Ophthalmol. 2012;130(10):1323-4. https://doi.org/10.1001/archophthalmol.2012.1504

94. Taha A, Badr MF, El-Morsy F, Hammad E. Report of $\beta$-lactam antibioticinduced vancomycin-resistant Staphylococcus aureus from a university hospital in Egypt. New Microbes New Infect. 2019;29:100507.

95. Whitener CJ, Park SY, Browne FA, Parent LJ, Julian K, Bozdogan B, Appelbaum PC, Chaitram J, Weigel LM, Jernigan J, McDougal LK, Tenover FC, Fridkin SK. Vancomycin-resistant Staphylococcus aureus in the absence of vancomycin exposure. Clin Infect Dis. 2004;38(8):1049-55. https:// doi.org/10.1086/382357.

96. Wong SS-Y, Ng T-K, Yam W-C, Tsang DN-C, Woo PC-Y, Fung SK-S, Yuen K-Y. Bacteremia due to Staphylococcus aureus with reduced susceptibility to vancomycin. Diagn Microbiol Infect Dis. 2000;36(4):261-8.

97. Haysom L, Cross M, Anastasas R, Moore E, Hampton S. Prevalence and risk factors for methicillin-resistant Staphylococcus aureus (MRSA) infections in custodial populations: a systematic review. J Correct Health Care. 2018:24(2):197-213.

98. Grema HA, Geidam YA, Gadzama GB, Ameh JA, Suleiman AJAAVS. Methicillin resistant Staphyloccus aureus (MRSA): a review. Adv Anim Vet Sci. 2015;3(2):79-98.
99. Tong SY, Lye DC, Yahav D, Sud A, Robinson JO, Nelson J, Archuleta S, Roberts MA, Cass A, Paterson DLJ. Effect of vancomycin or daptomycin with vs without an antistaphylococcal $\beta$-lactam on mortality, bacteremia, relapse, or treatment failure in patients with MRSA bacteremia: a randomized clinical trial. JAMA. 2020;323(6):527-37.

100. Yang C-C, Sy C-L, Huang Y-C, Shie S-S, Shu J-C, Hsieh P-H, Hsiao C-H, Chen C-JJSR. Risk factors of treatment failure and 30-day mortality in patients with bacteremia due to MRSA with reduced vancomycin susceptibility. Sci Rep. 2018;8(1):1-7.

101. Abdelhady W, Chen L, Bayer AS, Seidl K, Yeaman MR, Kreiswirth BN, Xiong YQ. Early agr activation correlates with vancomycin treatment failure in multi-clonotype MRSA endovascular infections. J Antimicrob Chemother. 2015;70(5):1443-52.

102. Bhattacharyya D, Banerjee J, Bandyopadhyay S, Mondal B, Nanda PK, Samanta I, Mahanti A, Das AK, Das G, Dandapat PJMDR. First report on vancomycin-resistant Staphylococcus aureus in bovine and caprine milk. J Clin Diagn Res. 2016;22(8):675-81.

103. Bandyopadhyay S, Samanta I, Bhattacharyya D, Nanda PK, Kar D, Chowdhury J, Dandapat P, Das AK, Batul N, Mondal BJVQ. Co-infection of methicillin-resistant Staphylococcus epidermidis, methicillin-resistant Staphylococcus aureus and extended spectrum $\beta$-lactamase producing Escherichia coli in bovine mastitis-three cases reported from India. Vet Q. 2015;35(1):56-61.

104. Al-Amery K, Elhariri M, Elsayed A, El-Moghazy G, Elhelw R, El-Mahallawy H, El Hariri M, Hamza DJAR, Control I. Vancomycin-resistant Staphylococcus aureus isolated from camel meat and slaughterhouse workers in Egypt. Antimicrob Resist Infect Control. 2019;8(1):129.

105. Diaz R, Ramalheira E, Afreixo V, Gago BJJogar, . Evaluation of vancomycin MIC creep in Staphylococcus aureus. J Glob Antimicrob Resist. 2017;10:281-4.

106. Diaz R, Afreixo V, Ramalheira E, Rodrigues C, Gago BJCM, Infection, . Evaluation of vancomycin MIC creep in methicillin-resistant Staphylococcus aureus infections-a systematic review and meta-analysis. Clin Microbiol Infect. 2018;24(2):97-104.

107. Chang W, Ma X, Gao P, Lv X, Lu H, Chen F. Vancomycin MIC creep in methicillin-resistant Staphylococcus aureus (MRSA) isolates from 2006 to 2010 in a hospital in China. Indian J Med Microbiol. 2015;33(2):262.

108. Wootton M, Howe R, Hillman R, Walsh T, Bennett P, MacGowan A. A modified population analysis profile (PAP) method to detect heteroresistance to vancomycin in Staphylococcus aureus in a UK hospital. J Antimicrob Chemother. 2001;47(4):399-403.

109. Semple A, O'Currain E, O'Donovan D, Hanahoe B, Keady D, Riain UN, Moylett E. Successful termination of sustained transmission of resident MRSA following extensive NICU refurbishment: an intervention study. J Hosp Infect. 2018;100(3):329-36.

110. Centers for Disease Control Prevention. CDC reminds clinical laboratories and healthcare infection preventionists of their role in the search and containment of vancomycin-resistant Staphylococcus aureus (VRSA). 2012.

111. EUCAST. European Committee on Antimicrobial Susceptibility Testing, Breakpoint tables for interpretation of MICs and zone diameters. Version 10.0 edn. European Society of Clinical Microbiology and Infectious Diseases Basel. 2020. http://www.eucast.org

112. Wayne P. Clinical and laboratory standards institute. Performance standards for antimicrobial susceptibility testing. 2018.

113. Gould IM. VRSA—doomsday superbug or damp squib? Lancet Infect Dis. 2010;10(12):816-8.

114. Weigel LM, Clewell DB, Gill SR, Clark NC, McDougal LK, Flannagan SE, Kolonay JF, Shetty J, Killgore GE, Tenover FCJS. Genetic analysis of a high-level vancomycin-resistant isolate of Staphylococcus aureus. Science. 2003;302(5650):1569-71.

115. Peng H, Liu D, Ma Y, Gao W. Comparison of community-and healthcareassociated methicillin-resistant Staphylococcus aureus isolates at a Chinese tertiary hospital, 2012-2017. Sci Rep. 2018;8(1):1-8.

116. Tsuji BT, Rybak MJ, Cheung CM, Amjad M, Kaatz GW. Community-and health care-associated methicillin-resistant Staphylococcus aureus: a comparison of molecular epidemiology and antimicrobial activities of various agents. Diagn Microbiol Infect Dis. 2007;58(1):41-7.

117. Kleinschmidt SL, Munckhof WJ, Nimmo GR. In vitro exposure of community-associated methicillin-resistant Staphylococcus aureus 
(MRSA) strains to vancomycin: does vancomycin resistance occur? Int J Antimicrob Agents. 2006;27(2):168-70.

118. Munckhof WJ, Kleinschmidt SL, Turnidge JD. Resistance development in community-acquired strains of methicillin-resistant Staphylococcus aureus: an in vitro study. Int J Antimicrob Agents. 2004;24(6):605-8.

119. Han JH, Edelstein PH, Lautenbach E. Reduced vancomycin susceptibility and staphylococcal cassette chromosome mec (SCC mec) type distribution in methicillin-resistant Staphylococcus aureus bacteraemia. J Antimicrob Chemother. 2012;67(10):2346-9.

\section{Publisher's Note}

Springer Nature remains neutral with regard to jurisdictional claims in published maps and institutional affiliations.
Ready to submit your research? Choose BMC and benefit from:

- fast, convenient online submission

- thorough peer review by experienced researchers in your field

- rapid publication on acceptance

- support for research data, including large and complex data types

- gold Open Access which fosters wider collaboration and increased citations

- maximum visibility for your research: over $100 \mathrm{M}$ website views per year

At BMC, research is always in progress.

Learn more biomedcentral.com/submissions 